1. A gradually increasing concentration of alkali in the reaction mixtures is on the whole unfavorable to the oxidation of all the bromotoluenes. A slightly alkaline solution is, however, more favorable than an entirely neutral medium.

2. An increasing dilution of the solution is favorable to the oxidation of all the bromotoluenes.

3. An excess of oxidizing agent above the calculated amount is favorable in all cases.

4. While the rates of oxidation of the bromotoluenes are essentially the same, the para compound gives the highest yield of the corresponding acid, the meta isomer next, and the ortho derivative the lowest.

5 . The essential point of difference between the results as above expressed, and those obtained in a similar investigation of the oxidation of the nitrotoluenes, is the fact that the presence of alkali in the reacting mixture was very favorable to the oxidation of $o$ - and $p$-nitrotoluene, while it is not so in the case of the corresponding bromotoluenes.

PROVIDENCE, RHODE ISLAND

[Con'tribution from the Division of Agricultural Chemistry of purdue: UNIVERSITY]

\title{
CHARACTERISTIC PROTEINS IN HIGH- AND LOW-PROTEIN CORN
}

\author{
By M. F. Showalter AND R. H. Carr \\ Received April 15, 1922
}

the nitrogen content of corn is subject to wide variations by breeding and selection.

Osborne and Mendel $^{1}$ reported a sample containing $2.33 \%$ of nitrogen, while in a more recent paper by Spitzer, Carr and Epple ${ }^{2}$ samples containing as low as $1.35 \%$ were reported. Average corn contains about $1.70 \%$ of nitrogen. The ear of highest nitrogen content that the writers have been able to produce is 2.95 and the lowest $1.29 \%$ of nitrogen. Since proteins are so important in nutrition it seems desirable to know whether the distribution of the various protcins is the same in high-nitrogen corn as in that of low nitrogen content, and if not to know wherein the difference lies.

Soave, ${ }^{3}$ an Italian worker, stated that the zein contains $32.65 \%$ of the total nitrogen of the corn kernel. Osborne and Mendel reported $22 \%$ of the total protein of corn with which they worked to be soluble in $10 \%$ potassium chloride solution, $41 \%$ soluble in $90 \%$ alcohol, $31 \%$ soluble in $0.2 \%$ potassium hydroxide solution, and $6 \%$ as insoluble and loss. Spitzer, Carr and Epple ${ }^{2}$ found $5.27 \%$ of the total nitrogen present as amides, $21.61 \%$ as globulin etc. (soluble in $10 \%$ sodium chloride solution), $29.41 \%$ as zein (soluble in $90 \%$ alcohol), and $42.85 \%$ as glutelin. From these data it is evident that there is a lack of agreement as to the distribution of the various proteins in corn. It is to be noted, however, that corn of relatively high nitrogen content $(2.33 \%)$ was used

\footnotetext{
${ }^{1}$ Osborne and Mendel, J. Biol. Chem., 18, 1 (1914).

2 Spitzer, Carr and Epple, This Journal, 41, 1212 (1919).

${ }^{3}$ Soave, C. A., 2, 150 (1908); Staz. Sper. Agr. Ital., 40, No. 3, 193-207 (1907).
} 
by Osborne and Mendel, while in the corn used by Spitzer, Carr and Epple, the average was only $1.702 \%$.

With these points in mind a study has been made of the relative abundance of the different proteins in high as compared with low nitrogen corn, and the respective mono- and di-amino acid contents. The results of the investigation are given in the tables which follow.

\section{Description of Corn Samples}

The high-nitrogen corn used in this determination was of the Champion White Pearl variety, except the pop corn samples, and was the result of many years of corn breeding, the seed having been originally selected because of its high nitrogen content. It contained $2.95 \%$ of nitrogen, equivalent to $18.43 \%$ of protein, of which $56.64 \%$ was soluble in $90 \%$ alcohol. This is noteworthy as it is a higher nitrogen content than any reported in the literature so far as the writers are aware, and the fraction of this nitrogen soluble in alcohol is considerably greater than any previously reported. The low-nitrogen corn was of the Yellow Dent variety and contained only $1.29 \%$ of nitrogen, equivalent to $8.06 \%$ of protein, of which only $27.47 \%$ was soluble in alcohol. Only those ears containing nitrogen equivalent to $14 \%$ or more of protein were selected as being representative of high-nitrogen corn, and only 2 ears were found which were low enough in nitrogen to be used in this investigation. All the samples were made into meal that would pass a 40 -mesh sieve. The ash content was determined to see whether it varied in proportion to the nitrogen content, but it seemed normal and no further attention was paid to it.

\section{Characteristic Proteins}

The nitrogen soluble in cold water was separated into two portions by precipitation with cupric sulfate in solution made alkaline by the addition

TABLE I

The Nitrogen of the Proteins in High- And Low-protein Corn

\begin{tabular}{|c|c|c|c|c|c|c|c|c|}
\hline \multirow{2}{*}{$\begin{array}{l}\text { Variety } \\
\text { of corn }\end{array}$} & \multirow[b]{2}{*}{ Sample } & \multirow{2}{*}{$\begin{array}{l}\text { Total N } \\
\text { in dry } \\
\text { weight } \\
\%\end{array}$} & \multirow{3}{*}{$\begin{array}{c}\text { Protein } \\
\mathrm{N} \times 6.25 \\
\% \\
18.43\end{array}$} & \multicolumn{5}{|c|}{ Results expressed in per cent. of total $N$} \\
\hline & & & & $\underset{\%}{\text { Amide }}$ & $\underset{\%}{\text { Albumin }}$ & $\begin{array}{c}\text { Globulin } \\
\%\end{array}$ & $\begin{array}{c}\text { Zein } \\
\%\end{array}$ & 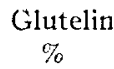 \\
\hline High-N & 16 & 2.95 & & & & & 56.64 & \\
\hline Champion & 11 & 2.66 & 16.62 & 2.50 & 4.47 & 3.20 & 38.01 & 51.82 \\
\hline White & 7 & 2.59 & 16.18 & 1.45 & 3.05 & 5.43 & 48.11 & 42.01 \\
\hline $\begin{array}{l}\text { Pearl } \\
\text { High-N }\end{array}$ & $\begin{array}{r}10 \\
7\end{array}$ & $\begin{array}{l}2.52 \\
2.48\end{array}$ & $\begin{array}{l}15.75 \\
15.40\end{array}$ & $\begin{array}{l}2.12 \\
4.88\end{array}$ & $\begin{array}{r}3.79 \\
4.93\end{array}$ & $\begin{array}{l}4.10 \\
1.57\end{array}$ & $\begin{array}{l}51.48 \\
48.83\end{array}$ & $\begin{array}{l}38.51 \\
39.79\end{array}$ \\
\hline Yellow & 3 & $\begin{array}{l}2.48 \\
2.36\end{array}$ & $\begin{array}{l}15.40 \\
14.75\end{array}$ & $\begin{array}{c}4.88 \\
\ldots\end{array}$ & $\begin{array}{c}4.93 \\
.\end{array}$ & $\begin{array}{c}1.08 \\
. .\end{array}$ & $\begin{array}{l}40.00 \\
52.71\end{array}$ & $\begin{array}{l}39.19 \\
35.97\end{array}$ \\
\hline $\begin{array}{l}\text { Dent } \\
\text { Low-N } \\
\text { Yellow }\end{array}$ & $\begin{array}{l}1 \\
3\end{array}$ & $\begin{array}{l}1.29 \\
1.35\end{array}$ & $\begin{array}{l}8.06 \\
8.43\end{array}$ & $\begin{array}{l}5.58 \\
6.92\end{array}$ & $\begin{array}{l}7.94 \\
8.49\end{array}$ & $\begin{array}{l}1.77 \\
1.29\end{array}$ & $\begin{array}{l}27.47 \\
36.24\end{array}$ & $\begin{array}{l}57.24 \\
47.06\end{array}$ \\
\hline $\begin{array}{l}\text { Dent } \\
\text { High-N } \\
\text { Pop corn }\end{array}$ & $\begin{array}{l}20 \\
16\end{array}$ & $\begin{array}{l}2.43 \\
2.31\end{array}$ & $\begin{array}{l}15.18 \\
14.43\end{array}$ & $\begin{array}{l}2.75 \\
2.29\end{array}$ & $\begin{array}{l}4.75 \\
3.93\end{array}$ & $\begin{array}{l}3.68 \\
5.74\end{array}$ & $\begin{array}{l}60.71 \\
53.77\end{array}$ & $\begin{array}{l}28.11 \\
34.27\end{array}$ \\
\hline
\end{tabular}


of sodium hydroxide according to the method developed by Blish ${ }^{4}$ and used by other workers ${ }^{2}$ in their determination of the amides in corn. The nitrogen of the filtrate was calculated as amide nitrogen and that of the residue as albumin nitrogen.

It will be noted in Table I that both the amides and albumin seem to form a considerably greater proportion of the total protein in corn of low nitrogen content. In the high-nitrogen corn the amides and albumin are less and the globulins, which were determined by extraction with $10 \%$ sodium chloride solution, ${ }^{4,9,11}$ form a larger part of the total protein. The most striking difference is in the protein zein, the part soluble in $90 \%$ alcohol. ${ }^{1,2}$ The proportion of zein to total protein is greater when the total nitrogen content of the corn is higher. This increased proportion of zein seems to be accompanied by a corresponding decrease in the proportion of glutelin. Table I shows that in corn containing about $2.50 \%$ of nitrogen $50 \%$ or more of this is present as zein, and that the protein of high-nitrogen pop corn is especially high in zein, one sample being as high as $60.71 \%$, accompanied by a rather low percentage of glutelin (28.11).

\section{Mono-amino and Di-amino Acid Content}

In order to study the nitrogen distribution the corn meal was hydrolyzed for 48 hours, using 35 parts of $20 \%$ hydrochloric acid for every gram of protein. ${ }^{5}$ The mono-amino and di-amino acids were then determined according to Van Slyke's method. ${ }^{6,7}$

TABLE II

$\mathrm{NH}_{3}$ nitrogen $\ldots \ldots \ldots \ldots \ldots \ldots \ldots \ldots$

Melanin $\mathrm{N}$.

Di-amino acid N....................

Total $\mathrm{N}$ in filtrate from bases.............

Amino $\mathrm{N}$ in filtrate...................

Non-amino $\mathrm{N}$ in filtrate.

Total $\mathrm{N}$ by summation.

\begin{tabular}{ccc}
$\begin{array}{c}\text { High N } \\
\text { Corn } \\
\%\end{array}$ & $\begin{array}{c}\text { Low N } \\
\text { Corn }\end{array}$ & $\begin{array}{c}\text { Analysis by } \\
\text { Grindley }\end{array}$ \\
5.46 & 5.26 & \multicolumn{1}{c}{$\%$} \\
8.14 & 12.07 & 12.53 \\
16.72 & 8.28 & 9.77 \\
71.76 & 76.63 & 63.84 \\
54.27 & 49.31 & 52.26 \\
17.49 & 27.32 & 11.17 \\
102.08 & 102.24 & 101.57
\end{tabular}

The data in Table II indicate that the basic or di-amino acids form a larger part of the total protein in the high-nitrogen corn $(16.72 \%)$ than in that of low nitrogen content (8.28). Similar results were obtained by other workers ${ }^{2}$ who gave the average di-amino acid content as $10.58 \%$ for corn containing $1.70 \%$ of nitrogen. The melanin content was less

${ }^{4}$ Blish, J. Biol. Chem., 33, 551 (1918).

${ }^{5}$ Van Slyke, ibid., 12, 295 (1912).

${ }^{6}$ Van Slyke, ibid., 10, 15 (1911-12).

7 Van Slyke, ibid., 12, 275 (1912).

${ }^{8}$ Grindley, Proc. Am. Soc. Animal Prod., 1915, p. 133. 
in the high-nitrogen corn than in the low, which may be due to the relatively greater amount of carbohydrates per part of nitrogen in the low-nitrogen corn. The amino nitrogen in the filtrate from the bases seems to be greater in the high-nitrogen corn than in that of low nitrogen content.

It will be noted from these data that the globulin is present in greater amount in the high-protein corn especially in the high protein pop corn. This may be due in part to the larger proportion of embryo to the rest of the seed, as it was found to make up between 14.5 and $15 \%$ of the total weight of the seed. The pop corn samples contained about the same percentage of embryo.

The usual amount found in dent corn, according to Hopkins ${ }^{9}$ is $11.53 \%$, whereas Babcock ${ }^{10}$ reports a few samples containing $13.71 \%$. It is the opinion of some writers that most of the globulin in the cereal grains resides in the embryo. The larger embryo in high nitrogen corn is probably responsible also for the high di-amino acid content noted. Brewster and Alsberg ${ }^{11}$ have shown that when nucleic acid (which is present in the embryo of seeds) is hydrolyzed, as was done in this case, $15 \%$ of the total nitrogen of the nucleic acid appears in the arginine fraction, although nucleic acid contains no arginine. Thus it is probable that the nucleic acid may account for part of the high percentage of di-amino acid reported.

It would seem, in conclusion, rather remarkable that it is possible through plant breeding to develop corn which is so far out of proportion in its nitrogen content from that ordinarily found. Since this appears to be true it would indicate that a balanced feed could be obtained in corn, providing that the proteins were of such a nature that they could be utilized during the process of digestion. Unpublished data, however, indicate that this nitrogen is not efficiently utilized by the animal.

\section{Summary}

A study has been made of the relative abundance of the different proteins in corn, and of the respective mono- and di-amino acid contents.

The data in Table I indicate that a considerably larger part of the protein is present as zein and globulins in high-nitrogen than in low-nitrogen corn, and that the zein and globulins have been formed at the expense of the amides, albumin and glutein.

The embryo makes up about $15 \%$ of total weight of high nitrogen corn grain, whereas dent corn of the usual composition has only about $11 \%$ of embryo.

It was found that zein was the protein which varied most, averaging $50.28 \%$ in high-nitrogen and only $31.85 \%$ in low-nitrogen corn.

${ }^{9}$ Hopkins, Illinois Bull., 1903, p. 77.

10 Babcock, Wisconsin Res. Bull., 22 (1912).

11 Brewster and Alsberg, J. Biol. Chem., 37, 367 (1919). 
The protein of high-nitrogen popcorn is especially high in zein, averaging $57.24 \%$.

The total nitrogen content seems to determine the amounts of the various proteins.

The amino nitrogen in the filtrate from the bases was found to be higher in the high-nitrogen corn than in that of low nitrogen content.

The di-amino acids form approximately twice as great a percentage of the total nitrogen in high-nitrogen as in low-nitrogen corn.

I,AFAYETTE, INDIANA

[CONTRIBUTION FROM THE DERMATOI,OGICAL RESEARCH INSTITUTE]

\section{CONDENSATION PRODUCTS OF ARSPHENAMINE WITH ALDEHYDES}

By George W. Raiziss and A. C. Blate ${ }^{2}$

Received May 16, 1922

\section{Introduction}

It has long been known that in many condensation reactions involving the carbonyl group of aldehydes or ketones, an intermediate addition product, in which the oxygen atom is converted into an hydroxyl group, is first formed. Ultimately the elements of water are split off, resulting in the formation of a second or final product. The isolation of these intermediate compounds, while often possible is, nevertheless, rare in those instances in which aromatic amines have been employed, as invariably water splits off producing the so-called Schiff Bases. Several exceptions may be observed in the condensations of chloral with aniline, $p$-toluidine or $p$-nitro-aniline; ${ }^{2}$ benzaldehyde with $m$-aminobenzoic acid, ${ }^{3}$ with $p$ nitro-aniline, ${ }^{4}$ with $p$-chloro- or $p$-bromo-aniline; ${ }^{5}$ resorcyl or pyrogallyl aldehyde with aniline. ${ }^{6}$ These products are very easily decomposed, either losing one molecule of water to form benzylidene compounds, or decomposing into the original constituents. They have basic properties, forming with acids, particularly hydrochloric acid, salts which are much more stable than the bases themselves. ${ }^{6}$ The stability of the latter depends upon the constituents employed. ${ }^{7}$ Thus, the benzaldehyde-aniline product is so easily decomposed that it cannot be isolated in pure form, while similat combinations with $p$-nitro-aniline or $\beta$-naphthylamine

${ }^{1}$ The authors are indebted to Mr. B. C. Fisher of this Institute for his valuable assistance in this work.

${ }^{2}$ Libner, Ann., 302, 361 (1898).

${ }^{3}$ A. Hantzsch and Kraft, Ber., 24, 3521 (1891).

"Miller and Rhode, itud,, 25, 2053 (1892).

"A. Hantzseh and Schwats, ibid., 34, 830 (1901).

' Dimroth and Zoeppritz, ilid., 35, 984 (1902).

7 Ref. 6. pp. 993-97. 